\title{
Flagellin Induces the Expression of Thymic Stromal Lymphopoietin in Human Keratinocytes via Toll-Like Receptor 5
}

\author{
Tuan Anh Le ${ }^{a-c}$ Toshiro Takai ${ }^{a}$ Anh Tuan Vu ${ }^{a, b, d}$ Hirokazu Kinoshita ${ }^{a, b}$ \\ Xue Chen $^{a, e}$ Shigaku Ikedaa, b Hideoki Ogawa ${ }^{a}$ Ko Okumura ${ }^{a}$

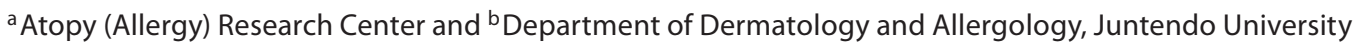 \\ Graduate School of Medicine, Tokyo, Japan; ${ }^{C}$ Department of Dermatology and Allergology, Institute of Clinical \\ Medical and Pharmaceutical Sciences 108, Hanoi, and dQuyhoa National Leprosy-Dermatology Hospital, \\ Quynhon, Vietnam; 'Department of Dermatology, Peking University People's Hospital, Beijing, China
}

\section{Key Words}

Thymic stromal lymphopoietin • Keratinocyte • Flagellin • Toll-like receptor 5 - Cytokine milieu - Atopic dermatitis • Thelper $2 \cdot$ Epidermal growth factor receptor ligand

\begin{abstract}
Background: Thymic stromal lymphopoietin (TSLP), highly expressed by keratinocytes in skin lesions of atopic dermatitis patients and bronchial epithelial cells in asthma, plays a key role in allergic diseases. Information on triggers for the release of TSLP in keratinocytes is still limited. Keratinocytes express Toll-like receptor (TLR) 5, the ligand for which is flagellin, the major structural protein of the flagella of Gramnegative bacteria. IL-4, IL-13 and TNF- $\alpha$ (Th2/TNF) are associated with allergic diseases. TGF- $\alpha$, one of the ligands for the epidermal growth factor receptor, is overexpressed in keratinocytes in atopic dermatitis. We investigated the induction of TSLP expression in keratinocytes stimulated with flagellin and its modulation by the Th2/TNF cytokines and TGF- $\alpha$. Methods: Primary human keratinocytes were stimulated with flagellin with or without cytokines. The TSLP released was measured by ELISA. Gene expression was analyzed by quantitative real-time PCR. Results: Stimulation of keratinocytes with flagellin induced the release of TSLP protein and
\end{abstract}

upregulation of the gene expression of TSLP and other proinflammatory molecules. The flagellin-induced release of TSLP was enhanced by the Th2/TNF cytokines or TGF- $\alpha$. Small interfering RNA-mediated knockdown of TLR5 expression suppressed the flagellin-induced TSLP gene expression. Conclusions: Flagellin induces TSLP expression in keratinocytes via TLR5 and the expression can be upregulated by a cytokine milieu with Th2/TNF or TGF- $\alpha$, suggesting that exposure of barrier-defective skin to Gram-negative bacteria or environmental flagellin contributes to the initiation and/ or amplification of Th2-type skin inflammation including atopic dermatitis through the induction of TSLP expression in keratinocytes.

Copyright $\odot 2010$ S. Karger AG, Basel

\section{Introduction}

Thymic stromal lymphopoietin (TSLP), highly expressed by keratinocytes in skin lesions of atopic dermatitis (AD) patients and bronchial epithelial cells of asthma patients, plays a key role in allergic diseases $[1,2]$. TSLPactivated dendritic cells secrete Th2-recruiting chemokines but not IL-12, and induce naïve T cells to differentiate into inflammatory Th2 cells producing IL-4, IL-5, IL-

\section{KARGER}

Fax +41613061234 E-Mail karger@karger.ch www.karger.com

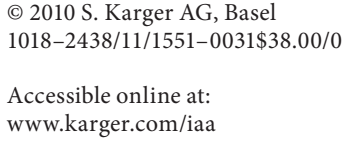


13 and TNF- $\alpha$ through the OX40 ligand [1]. TSLP similarly activates epidermal Langerhans cells, a subset of dendritic cells [3]. The TSLP-activated dendritic cells can cause allergen-specific Th2 memory cells to undergo homeostatic expansion and further Th2 polarization and to mediate recall responses [4]. TSLP can also act directly on human mast cells synergistically with IL-1 and TNF- $\alpha$ to produce IL-5 and IL-13 [5], and on human CD4+ T cells activated with TCR stimulation to induce marked proliferation [6]. Thus, TSLP represents a critical factor linking responses at interfaces between the body and environment to allergic type 2 immune responses.

Information on environmental and endogenous triggers for the release of TSLP in keratinocytes is still limited. Pro-inflammatory and Th2 cytokines act synergistically to induce the release of TSLP from human skin explants obtained from healthy donors [7]. Recently, we demonstrated that polyinosinic-polycytidylic acid, a synthetic double-stranded RNA (dsRNA) recognized potentially by dsRNA sensors including Toll-like receptor (TLR) 3, is a trigger for TSLP production in primary human keratinocytes [8-10], and the release can be synergistically enhanced with an atopic cytokine milieu [8]. Very recently, an endogenous protease, kallikrein 5, was found to induce the expression of TSLP in keratinocytes via protease-activated receptor 2 [11].

Keratinocytes express TLR5 [12-15], the ligand for which is flagellin [16], the major structural protein of the flagella of Gram-negative bacteria. In our recent study, flagellin induced the release of IL-8 but not TSLP in keratinocytes in the presence of hydrocortisone without the addition of cytokines in the culture medium [8]. However, glucocorticoids such as hydrocortisone inhibited $[17,18]$ and an atopic cy tokine milieu with IL-4, IL-13 and TNF- $\alpha$ (Th2/TNF- $\alpha$ ) enhanced [8] the dsRNA-induced release of TSLP in keratinocytes. In the present study, we examine the capacity of flagellin to induce TSLP expression in the absence of hydrocortisone and in the presence of cytokines, which compose the cytokine milieu associated with AD.

\section{Materials and Methods}

\section{Reagents}

The following concentrations of recombinant human cytokines and flagellin were used to stimulate keratinocytes: $20 \mathrm{ng} / \mathrm{ml}$ TNF- $\alpha, 100$ ng/ml IL-4, 100 ng/ml IL-13 (R\&D Systems, Minneapolis, Minn., USA), 50 ng/ml TGF- $\alpha$ (Calbiochem, San Diego, Calif., USA) and 1-100 ng/ml flagellin purified from Salmonella typhimurium strain 14028 (Alexis Biochemicals, San Diego, Calif., USA).
Cell Culture and Stimulation of Keratinocytes

Primary human keratinocytes (Cascade Biologics, Portland, Oreg., USA) were cultured in EpiLife KG2 (Kurabo, Osaka, Japan) supplemented with $0.1 \mathrm{ng} / \mathrm{ml}$ epidermal growth factor, $10 \mu \mathrm{g} / \mathrm{ml}$ insulin, $0.5 \mu \mathrm{g} / \mathrm{ml}$ hydrocortisone, $50 \mu \mathrm{g} / \mathrm{ml}$ gentamycin, $50 \mathrm{ng} / \mathrm{ml}$ amphotericin $\mathrm{B}$ and $0.4 \% \mathrm{vol} / \mathrm{vol}$ bovine brain pituitary extract. Cells were seeded at $8 \times 10^{3}$ cells/well in flat-bottomed 96 -well microculture plates (for ELISA) or $6 \times 10^{4}$ in 12 -well plates (for PCR) and cultured until they reached $100 \%$ confluence, and then the medium was changed to medium without hydrocortisone. After further cultivation for $24 \mathrm{~h}$, cells were stimulated with flagellin with or without cytokines in fresh medium without hydrocortisone.

Transfections of Keratinocytes with Small Interfering RNA

Keratinocytes at $60-70 \%$ confluence in 12-well tissue culture plates were transfected with the following Stealth small interfering RNAs (siRNAs) (Invitrogen, Carlsbad, Calif., USA) using Lipofectamine 2000 (Invitrogen): TLR5-siRNA1, 5'-AAUUCAACUUCCCAAAUGAAGGAUG-3'; TLR5-siRNA2, 5'-UCAGAUGGCUAAAUACUCCUGGUGG-3'; control siRNA1 (scrambled sequence of TLR5-siRNA1), 5'-AAUGGUCAACCCUUAAACAAGUAUG-3'; control siRNA2 (scrambled sequence of TLR5siRNA2), 5'-UCAGGAGGGUAUCUAAUCAUCCUGG-3'. Lipofectamine $2000(4 \mu \mathrm{l})$ was mixed with $2 \mu \mathrm{l}$ of a $20-\mu \mathrm{M}$ siRNA solution and $100 \mu$ l of OPTI-MEM (Gibco BRL, Gaithersburg, Md., USA). After incubation for $30 \mathrm{~min}$ at room temperature, a total of $500 \mu \mathrm{l}$ of basal medium without the supplements was added and the solution $(600 \mu \mathrm{l})$ was added to each of the wells. After cultivation with siRNAs for $24 \mathrm{~h}$, the medium was changed to hydrocortisone-free medium. After further cultivation for $24 \mathrm{~h}$, keratinocytes were stimulated with flagellin.

ELISA

Concentrations of TSLP and IL-8 proteins were measured with ELISA kits (DuoSet; R\&D Systems) using diluted (1:2 for TSLP and less than 1:30 for IL-8) culture supernatant collected at 24,48 or $72 \mathrm{~h}$ after the stimulation. In this study, the detection limit for TSLP and IL-8 in the supernatant was 3.9 and $156 \mathrm{pg} / \mathrm{ml}$, respectively. A one-way analysis of variance (ANOVA) with Tukey's multiple comparison test or t test (two-tailed) was used. Values of $\mathrm{p}<0.05$ were regarded as statistically significant.

\section{Real-Time Quantitative PCR}

Total RNA was extracted from the cells and cDNA was synthesized as described previously [8]. Real-time quantitative PCR was performed using a Taqman method with an ABI7500 (Applied Biosystems, Piscataway, N.J., USA). The mRNA level was normalized to the gene expression of $\beta$-actin and is shown as relative to the control level.

\section{Results}

Flagellin Induced Upregulation of Gene Expression of TSLP and Other Pro-Inflammatory Molecules in Keratinocytes

We examined whether flagellin stimulates primary human keratinocytes to upregulate TSLP gene expres- 
sion in the absence of hydrocortisone. After cultivation in the absence of hydrocortisone for $24 \mathrm{~h}$, keratinocytes were stimulated in the absence of hydrocortisone. Stimulation of keratinocytes with flagellin induced the gene expression of not only TSLP but also other pro-inflammatory molecules (fig. 1): cy tokines (TSLP, TNF- $\alpha$, IL- 6 and GM-CSF), chemokines (CCL2/monocyte chemoattractant protein 1, CCL5/RANTES, CCL20/macrophage inflammatory protein $3 \alpha$, CCL27/cutaneous T cell-attracting chemokine, CXCL8/IL-8 and CXCL10/IFN-inducible protein 10) and an adhesion molecule (CD54/ICAM-1).

Flagellin Induced Upregulation of TSLP Gene Expression in Keratinocytes Synergistically with Th2/TNF- $\alpha$ Cytokines

The combination of flagellin and Th2/TNF cytokines (IL-4, IL-13 and TNF- $\alpha$ ) mimicking atopic cytokine milieu showed synergistic effects on the upregulation of the gene expression of TSLP and IL-8 (fig. 2a).

\section{Flagellin Induced the Release of TSLP Protein}

in Keratinocytes in the Presence of Th2/TNF- $\alpha$

Cytokines

Flagellin induced the release of TSLP and IL- 8 in the absence of hydrocortisone and in the presence of Th2/ TNF- $\alpha$ cytokines (fig. $2 b$ ). Less TSLP and IL- 8 were released in the absence of the Th2/TNF cytokines than in their presence (fig. 3).

\section{TGF- $\alpha$ Upregulated Flagellin-Induced Release of}

TSLP

TGF- $\alpha$, one of the ligands for the epidermal growth factor receptor (EGFR) [19], is highly expressed in keratinocytes of patients with psoriasis, AD and allergic contact hypersensitivity [20]. TGF- $\alpha$ regulates the response of keratinocytes to flagellin [14]. Therefore, next we examined whether TGF- $\alpha$ enhances the flagellin-induced release of TSLP. Similarly to the Th2/TNF- $\alpha$ cytokines, TGF- $\alpha$ promoted the flagellin-induced release of TSLP and IL-8 (fig. 3). Less IL- 8 was released by TGF- $\alpha$ than by the Th2/TNF- $\alpha$ cytokines (fig. 3b). However, the addition of Th2/TNF cytokines in presence of TGF- $\alpha$ did not further enhance the release of TSLP (fig. 4a), although it enhanced the release of IL-8 (fig. $4 \mathrm{~b}$ ).

\section{Flagellin Induced TSLP Gene Expression in}

Keratinocytes via TLR5

Knockdown of TLR5 gene expression by siRNA (fig. 5a) reduced the flagellin-induced upregulation of TSLP gene expression (fig. 5b). In comparison to trans-

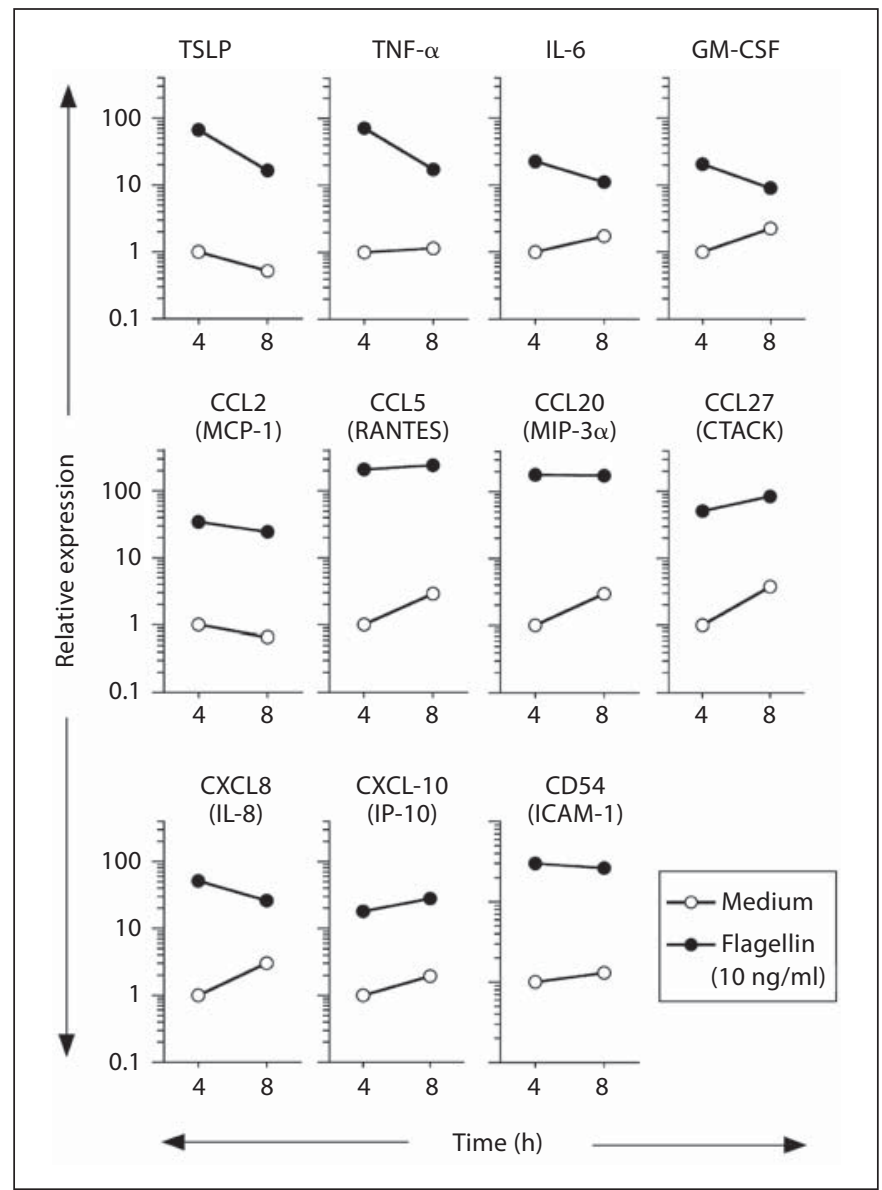

Fig. 1. Flagellin induced upregulation of gene expression of TSLP and other pro-inflammatory molecules in keratinocytes. The expression of mRNA at 4 and $8 \mathrm{~h}$ after stimulation was analyzed by quantitative real-time PCR and is presented as fold change relative to the medium at $4 \mathrm{~h}$. Data shown are for single wells and are representative of 3 independent experiments with similar results.

fection with control siRNAs (control siRNA1 and control siRNA2) with the scrambled sequence of the TLR5 siRNAs, transfection with the TLR5 siRNAs (TLR5siRNA1 or TLR5-siRNA2) successfully decreased the TLR5 gene expression with or without stimulation with flagellin and inhibited the flagellin-induced upregulation of TSLP gene expression.

\section{Discussion}

We demonstrated that flagellin has the capacity to induce the gene expression (fig. 1, 2a) and release (fig. 2b, 3, 4) of TSLP in primary human keratinocytes. Th2/TNF 
Fig. 2. Flagellin induced release of TSLP in keratinocytes in the presence of Th2/ TNF- $\alpha$ cytokines. a The expression of TSLP and IL- 8 mRNA at $8 \mathrm{~h}$ after stimulation was analyzed by quantitative realtime PCR and is represented as fold change relative to the medium. Data shown are for single wells and are representative of three independent experiments with similar results. b Amounts of TSLP and IL-8 released at $48 \mathrm{~h}$ after stimulation were measured. The broken line shows the minimum detectable limit. ${ }^{*} \mathrm{p}<0.05$ versus Th2/TNF- $\alpha$ by t test (two tailed). Data shown are the means \pm SD for 3 wells and are representative of 3 independent experiments with similar results. a
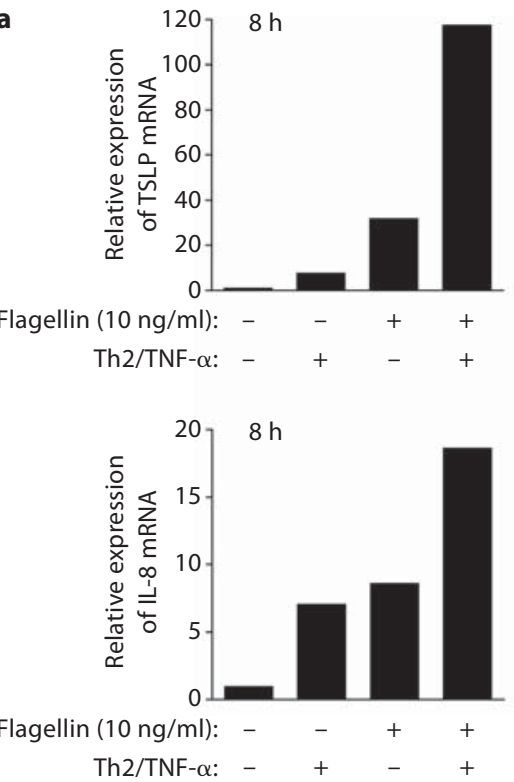

b
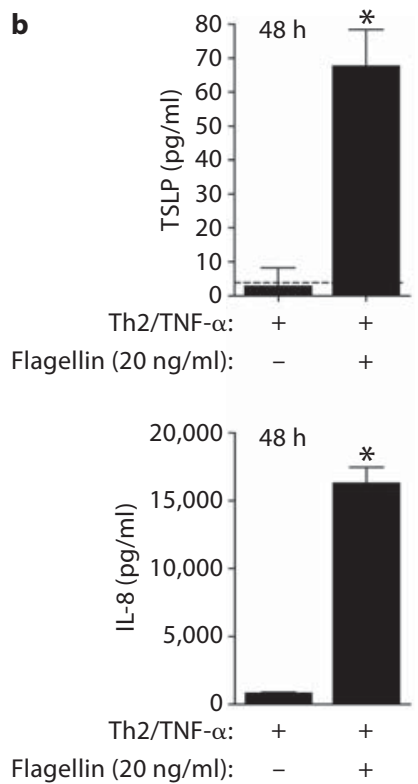

a

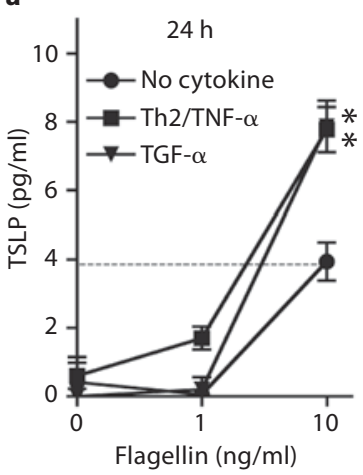

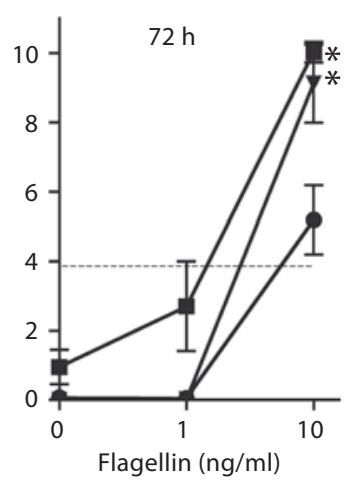

b

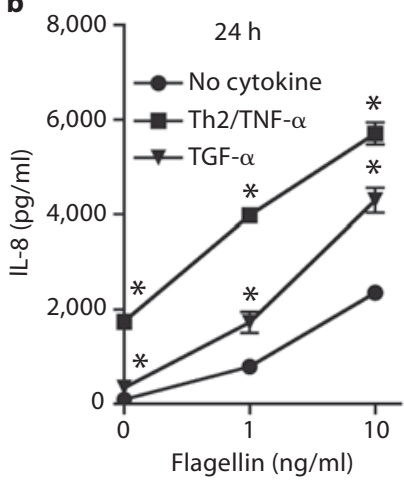

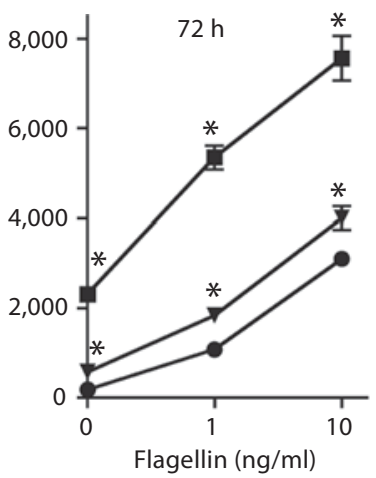

Fig. 3. Th2/TNF- $\alpha$ cytokines and TGF- $\alpha$ enhanced flagellin-induced release of TSLP in keratinocytes. Amounts of TSLP (a) and IL-8 (b) released at $24 \mathrm{~h}$ (left) and $72 \mathrm{~h}$ (right) after stimulation were measured. The broken line shows the minimum detectable limit. ${ }^{*} \mathrm{p}<0.05$ versus no cytokine by ANOVA with the Tukey multiple comparison test. Data shown are the means \pm SD for 3 wells and are representative of 3 independent experiments with similar results. cytokines (fig. 2, 3) or TGF- $\alpha$ (fig. 3, 4) enhanced the flagellin-induced release of TSLP. Flagellin induced the TSLP expression via TLR5 (fig. 5). The data in the present study were obtained using purified natural flagellin (fig. 1-5). Recombinant flagellin also induced the similar amount of release of TSLP (data not shown). Flagellin induced upregulation of gene expression of not only TSLP but also other pro-inflammatory molecules (fig. 1). However, no or little upregulation of IFN- $\beta$ gene expression was observed at $4 \mathrm{~h}$ after the stimulation with flagellin (data not shown), while dsRNA strongly upregulated the IFN- $\beta$ expression $[8,18]$. This is not surprising because interferon-regulatory factor 3 , the transcription factor essential for induction of IFN- $\beta$, can be activated via dsRNA 
Fig. 4. Th2/TNF- $\alpha$ cytokines and TGF- $\alpha$ showed no synergism in enhancement of flagellin-induced release of TSLP in keratinocytes. In the presence of TGF- $\alpha$, keratinocytes were stimulated with flagellin and/or Th2/TNF- $\alpha$ cytokines. Amounts of TSLP (a) and IL-8 (b) released at $24 \mathrm{~h}$ after stimulation were measured. The broken line shows the minimum detectable limit. ${ }^{*} \mathrm{p}<0.05$ versus without TGF- $\alpha$ alone by ANOVA with the Tukey multiple comparison test; ${ }^{+} \mathrm{p}<0.05$ versus without Th2/TNF- $\alpha$ cytokines by $t$ test (twotailed). Data shown are the means $\pm \mathrm{SD}$ for 3 wells and are representative of 3 independent experiments with similar results.

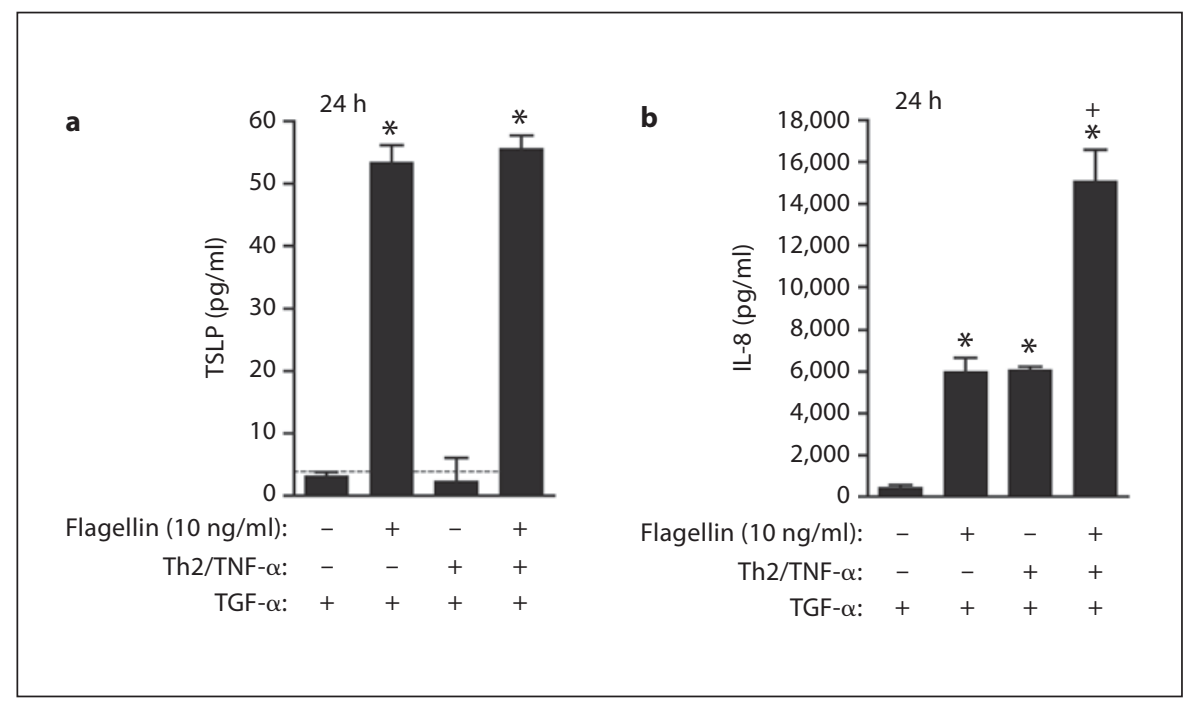

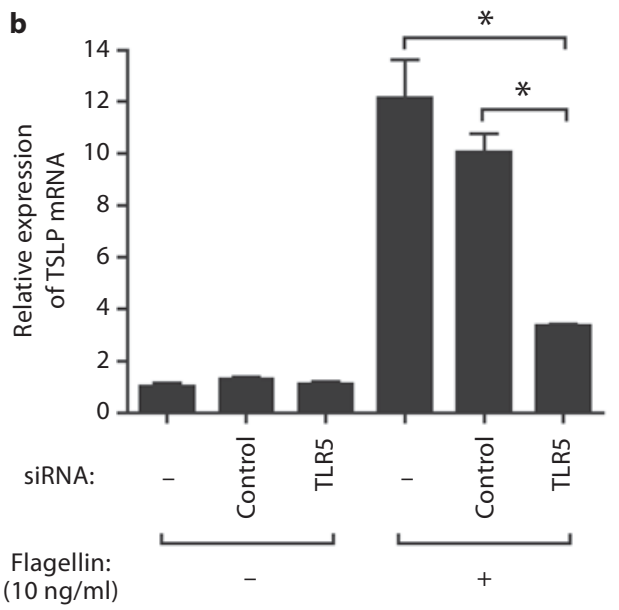

Fig. 5. Knockdown of TLR5 reduced flagellin-induced upregulation of TSLP gene expression. Keratinocytes were transfected with the TLR5 siRNA (TLR5) or the control siRNA (control) with the scrambled sequence of the TLR 5 siRNA. The expression of TLR5 (a) and TSLP (b) mRNA at $8 \mathrm{~h}$ after stimulation was analyzed by quantitative real-time PCR and is represented as fold change relative to keratinocytes treated with vehicle alone without siRNA without stimulation with flagellin. The sequences of the siRNAs used are described in the Materials and Methods section. The results shown were obtained using TLR5-siRNA2 and control siRNA2. Similar results were obtained with TLR5siRNA1 and control siRNA1. ${ }^{*} \mathrm{p}<0.05$ versus the TLR5 siRNA by ANOVA with the Tukey multiple comparison test. Data shown are the means \pm SD for 3 wells and are representative of 3 independent experiments with similar results. sensors such as TLR3, retinoic acid-inducible gene I and melanoma differentiation antigen 5 , but not via TLR5 [21]. The induction level of TSLP seems different among donors of keratinocytes and/or experimental conditions (for example, between fig. 4 and 5; data not shown), which might be attributed to genetic polymorphisms of genes of TSLP [22] or other molecules such as sensors, signaling molecules, transcription factors and so on [10].

Flagellin is the major structural protein of the flagella of Gram-negative bacteria. Two receptors, the cell-sur- 
face TLR5 and the intracellular receptor Ipaf, have been reported to recognize flagellin $[16,23]$. Keratinocytes express TLR5 and can respond to flagellin [12-15, 24, 25]. Flagellin induced TSLP expression in a TLR5-dependent manner in keratinocytes (fig. 5). As another component of Gram-negative bacteria, LPS, is present in house dust [26], flagellin also might be present in house dust. Barrier dysfunction in the skin occurs in infancy at high frequency, is genetically determined or is induced by endogenous or environmental factors [27-33]. Exposure of barrier-defected skin to Gram-negative bacteria or environmental flagellin might contribute to the initiation and/or amplification of Th2 inflammation via the induction of TSLP expression in keratinocytes.

Th2/TNF- $\alpha$ cytokines or TGF- $\alpha$ enhanced the flagellin-induced release of TSLP (fig. 2-4). Very recently, the expression of TSLP induced by flagellin in primary human corneal epithelial cells and its enhancement by Th2 cytokines have been reported [34]. Th2 cytokines or proinflammatory cytokines have been also reported to induce the release of TSLP from human skin explants obtained from healthy donors [7], and upregulate dsRNAinduced release of TSLP in primary human keratinocytes [8] and primary human bronchial epithelial cells [35]. TGF- $\alpha$ is one of the ligands for EGFR [19]. Crosstalk between TLR5- and EGFR-driven events has been suggested $[14,19]$.

A Th2 and/or inflammatory cytokine milieu can be provided to keratinocytes through interaction with allergen-specific Th2 cells, mast cells, basophils and so on. Howell et al. [30] demonstrated that a Th2 cytokine mi- lieu contributes to a reduction in the expression of filaggrin, which is critical for an effective skin barrier and whose genetic mutations are a major predisposing factor for AD [29]. TGF- $\alpha$ is overexpressed in keratinocytes in psoriasis, AD and allergic contact hypersensitivity [20]. The release of TSLP induced by flagellin could be more effective in AD skin than in healthy skin because of (1) a barrier defect caused in infancy or by genetic and environmental factors in $\mathrm{AD},(2)$ an association of $\mathrm{AD}$ with Th2 inflammation $[36,37]$ and allergen-specific IgE, which stimulates mast cells and basophils to produce such cytokines through the high-affinity IgE receptor on exposure to allergens [38], and (3) the overexpression of TGF- $\alpha$ in keratinocytes in AD [20].

In summary, we demonstrated that flagellin induces TSLP expression via TLR5 in keratinocytes. The results suggest that exposure of skin with barrier defect to Gramnegative bacteria or environmental flagellin, which might be contained in house dust, contributes to the initiation and/or amplification of Th2 inflammatory responses in the skin such as AD via the induction of TSLP expression in keratinocytes. How flagellin actually impacts skin inflammation remains to be investigated.

\section{Acknowledgements}

The authors thank Seiji Kamijo, Takasuke Ogawa, Mutsuko Hara and Yang Xie for technical advice and assistance, Tadashi Baba for helpful comments, and Michiyo Matsumoto for secretarial assistance.

\section{References}

1 Liu YJ: Thymic stromallymphopoietin: master switch for allergic inflammation. J Exp Med 2006;203:269-273.

-2 Soumelis V, Reche PA, Kanzler H, Yuan W, Edward G, Homey B, Gilliet M, Ho S, Antonenko S, Lauerma A, Smith K, Gorman D, Zurawski S, Abrams J, Menon S, McClanahan T, de Waal-Malefyt Rd R, Bazan F, Kastelein RA, Liu YJ: Human epithelial cells trigger dendritic cell mediated allergic inflammation by producing TSLP. Nat Immunol 2002;3:673-680.

3 Ebner S, Nguyen VA, Forstner M, Wang YH, Wolfram D, Liu YJ, Romani N: Thymic stromal lymphopoietin converts human epidermal Langerhans cells into antigen-presenting cells that induce proallergic $\mathrm{T}$ cells. J Allergy Clin Immunol 2007;119:982-990.
4 Wang YH, Ito T, Wang YH, Homey B, Watanabe N, Martin R, Barnes CJ, McIntyre BW Gilliet M, Kumar R, Yao Z, Liu YJ: Maintenance and polarization of human $\mathrm{TH} 2$ central memory $\mathrm{T}$ cells by thymic stromal lymphopoietin-activated dendritic cells. Immunity 2006;24:827-838.

5 Allakhverdi Z, Comeau MR, Jessup HK, Yoon BR, Brewer A, Chartier S, Paquette N, Ziegler SF, Sarfati M, Delespesse G: Thymic stromal lymphopoietin is released by human epithelial cells in response to microbes, trauma, or inflammation and potently activates mast cells. J Exp Med 2007;204:253-258.

6 Rochman I, Watanabe N, Arima K, Liu YJ, Leonard WJ: Cutting edge: direct action of thymic stromal lymphopoietin on activated human CD4+ T cells. J Immunol 2007;178: 6720-6724.
7 Bogiatzi SI, Fernandez I, Bichet JC, MarloieProvost MA, Volpe E, Sastre X, Soumelis V: Cutting Edge: proinflammatory and Th2 cytokines synergize to induce thymic stromal lymphopoietin production by human skin keratinocytes. J Immunol 2007;178:33733377.

$>8$ Kinoshita H, Takai T, Le TA, Kamijo S, Wang XL, Ushio H, Hara M, Kawasaki J, Vu AT, Ogawa T, Gunawan H, Ikeda S, Okumura K, Ogawa H: Cytokine milieu modulates release of thymic stromal lymphopoietin from human keratinocytes stimulated with double-stranded RNA. J Allergy Clin Immunol 2009;123:179-186. 
9 Seidl B, Kalali B, Gerhard M, Ring J, Ollert M, Mempel M: Thymic stromal lymphopoietin induction by polyinosinic:polycytidylic acid in human keratinocytes is preferentially mediated through protein kinase $\mathrm{R}$ and retinoid-inducible gene I and not Toll-like receptor 3. J Allergy Clin Immunol 2009;124: 862-864.

-10 Takai T, Vu AT, Le TA, Kinoshita H, Ushio H, Ikeda S, Ogawa H, Okumura K: Reply. J Allergy Clin Immunol 2009;124:864-865.

-11 Briot A, Deraison C, Lacroix M, Bonnart C, Robin A, Besson C, Dubus P, Hovnanian A: Kallikrein 5 induces atopic dermatitis-like lesions through PAR2-mediated thymic stromal lymphopoietin expression in Netherton syndrome. J Exp Med 2009;206:11351147.

-12 Baker BS, Ovigne JM, Powles AV, Corcoran S, Fry L: Normal keratinocytes express Tolllike receptors (TLRs) 1, 2 and 5: modulation of TLR expression in chronic plaque psoriasis. Br J Dermatol 2003;148:670-679.

13 Kollisch G, Kalali BN, Voelcker V, Wallich R, Behrendt H, Ring J, Bauer S, Jakob T, Mempel M, Ollert M: Various members of the Toll-like receptor family contribute to the innate immune response of human epidermal keratinocytes. Immunology 2005;114:531541.

-14 Miller LS, Sorensen OE, Liu PT, Jalian HR, Eshtiaghpour D, Behmanesh BE, Chung W, Starner TD, Kim J, Sieling PA, Ganz T, Modlin RL: TGF- $\alpha$ regulates TLR expression and function on epidermal keratinocytes. J Immunol 2005;174:6137-6143.

-15 Lebre MC, van der Aar AM, van Baarsen L, van Capel TM, Schuitemaker JH, Kapsenberg ML, de Jong EC: Human keratinocytes express functional Toll-like receptor 3, 4, 5, and 9. J Invest Dermatol 2007;127:331-341.

16 Hayashi F, Smith KD, Ozinsky A, Hawn TR, Yi EC, Goodlett DR, Eng JK, Akira S, Underhill DM, Aderem A: The innate immune response to bacterial flagellin is mediated by Toll-like receptor 5. Nature 2001;410:10991103.

-17 Le TA, Takai T, Kinoshita H, Suto H, Ikeda S, Okumura K, Ogawa H: Inhibition of double-stranded RNA-induced TSLP in human keratinocytes by glucocorticoids. Allergy 2009;64:1231-1232.

-18 Le TA, Takai T, Vu AT, Kinoshita H, Ikeda S, Ogawa H, Okumura K: Glucocorticoids inhibit double-stranded RNA-induced TSLP release from keratinocytes in atopic cytokine milieu more effectively than tacrolimus. Int Arch Allergy Immunol 2010;153:27-34.
19 Pastore S, Mascia F, Mariani V, Girolomoni $\mathrm{G}$ : The epidermal growth factor receptor system in skin repair and inflammation. J Invest Dermatol 2008;128:1365-1374.

20 Mascia F, Mariani V, Girolomoni G, Pastore S: Blockade of the EGF receptor induces a deranged chemokine expression in keratinocytes leading to enhanced skin inflammation. Am J Pathol 2003;163:303-312.

21 Kumar H, Kawai T, Akira S: Pathogen recognition in the innate immune response. Biochem J 2009;420:1-16.

22 Harada M, Hirota T, Jodo AI, Doi S, Kameda M, Fujita K, Miyatake A, Enomoto T, Noguchi E, Yoshihara S, Ebisawa M, Saito H, Matsumoto K, Nakamura Y, Ziegler SF, Tamari M: Functional analysis of the thymic stromal lymphopoietin variants in human bronchial epithelial cells. Am J Respir Cell Mol Biol 2009;40:368-374.

23 Miao EA, Alpuche-Aranda CM, Dors M, Clark AE, Bader MW, Miller SI, Aderem A: Cytoplasmic flagellin activates caspase-1 and secretion of interleukin $1 \beta$ via Ipaf. Nat Immunol 2006;7:569-575.

24 Abtin A, Eckhart L, Mildner M, Gruber F, Schroder JM, Tschachler E: Flagellin is the principal inducer of the antimicrobial peptide S100A7c (psoriasin) in human epidermal keratinocytes exposed to Escherichia coli. FASEB J 2008;22:2168-2176.

25 Niyonsaba F, Hattori F, Maeyama K, Ogawa $\mathrm{H}$, Okamoto $\mathrm{K}$ : Induction of a microbicidal protein psoriasin (S100A7), and its stimulatory effects on normal human keratinocytes. J Dermatol Sci 2008;52:216-219.

26 Liu AH: Endotoxin exposure in allergy and asthma: reconciling a paradox. J Allergy Clin Immunol 2002;109:379-392.

-27 Ogawa H, Yoshiike T: A speculative view of atopic dermatitis: barrier dysfunction in pathogenesis. J Dermatol Sci 1993;5:197204.

28 Boralevi F, Hubiche T, Leaute-Labreze C, Saubusse E, Fayon M, Roul S, Maurice-Tison S, Taieb A: Epicutaneous aeroallergen sensitization in atopic dermatitis infants determining the role of epidermal barrier impairment. Allergy 2008;63:205-210.

29 Palmer CN, Irvine AD, Terron-Kwiatkowski A, Zhao Y, Liao H, Lee SP, Goudie DR, Sandilands A, Campbell LE, Smith FJ, O'Regan GM, Watson RM, Cecil JE, Bale SJ, Compton JG, DiGiovanna JJ, Fleckman P, Lewis-Jones S, Arseculeratne G, Sergeant A, Munro CS, El Houate B, McElreavey K, Halkjaer LB, Bisgaard $\mathrm{H}$, Mukhopadhyay S, McLean WH: Common loss-of-function variants of the epidermal barrier protein filaggrin are a major predisposing factor for atopic dermatitis. Nat Genet 2006;38:441-446.
30 Howell MD, Kim BE, Gao P, Grant AV, Boguniewicz M, Debenedetto A, Schneider L, Beck LA, Barnes KC, Leung DY: Cytokine modulation of atopic dermatitis filaggrin skin expression. J Allergy Clin Immunol 2007;120:150-155.

-31 Nakamura T, Hirasawa Y, Takai T, Mitsuishi K, Okuda M, Kato T, Okumura K, Ikeda S, Ogawa $\mathrm{H}$ : Reduction of skin barrier function by proteolytic activity of a recombinant house dust mite major allergen Der f 1 . J Invest Dermatol 2006;126:2719-2723.

>32 Hirasawa Y, Takai T, Nakamura T, Mitsuishi K, Gunawan H, Suto H, Ogawa T, Wang XL, Ikeda S, Okumura K, Ogawa H: Staphylococcus aureus extracellular protease causes epidermal barrier dysfunction. J Invest Dermatol 2010;130:614-617.

33 Okuda M, Yoshiike T, Ogawa H: Detergentinduced epidermal barrier dysfunction and its prevention. J Dermatol Sci 2002;30:173179.

-34 Ma P, Bian F, Wang Z, Zheng X, Chotikavanich S, Pflugfelder SC, Li DQ: Human corneal epithelium-derived thymic stromal lymphopoietin links the innate and adaptive immune responses via TLRs and Th2 cytokines. Invest Ophthalmol Vis Sci 2009;50: 2702-2709.

-35 Kato A, Favoreto S Jr, Avila PC, Schleimer RP: TLR3-and Th2 cytokine-dependent production of thymic stromal lymphopoietin in human airway epithelial cells. J Immunol 2007;179:1080-1087.

36 Hamid Q, Boguniewicz M, Leung DY: Differential in situ cytokine gene expression in acute versus chronic atopic dermatitis. J Clin Invest 1994;94:870-876.

-37 Teraki Y, Hotta T, Shiohara T: Increased circulating skin-homing cutaneous lymphocyte-associated antigen (CLA)+ type 2 cytokine-producing cells, and decreased CLA+ type 1 cytokine-producing cells in atopic dermatitis. Br J Dermatol 2000;143:373-378.

38 Kawakami T, Galli SJ: Regulation of mastcell and basophil function and survival by IgE. Nat Rev Immunol 2002;2:773-786. 